\title{
Effect of dietary protein concentration on responses to Escherichia coli endotoxin in broiler chickens
}

\author{
BY KAZUAKI TAKAHASHI, SHINICHI YODOGAWA AND YUKIO AKIBA \\ Department of Animal Science, Faculty of Agriculture, Tohoku University, Sendai-shi Japan 981
}

AND KEIJI TAMURA

Saikin Kagaku Institute, Sendai-shi Japan 981

(Received 8 September 1994 - Revised 6 December 1994-Accepted 6 January 1995)

\begin{abstract}
The effect of dietary protein concentration on stress responses against injection of Escherichia coli lipopolysaccharide (LPS) was studied in male broiler chickens. Chickens ( $7 \mathrm{~d}$ of age) were fed on a 100 (low-protein; LP) or $300 \mathrm{~g}$ protein/kg (high-protein; HP) diet for 2 weeks. LPS was injected intraperitoneally every $2 \mathrm{~d}$ during the final $6 \mathrm{~d}$, or once $16 \mathrm{~h}$ before the end of the experiment, at a concentration of $900 \mu \mathrm{g} / \mathrm{chick}$. The LPS injection did not affect body-weight gain, feed intake, gain:intake ratio, or plasma Fe concentration. The single injection of LPS reduced plasma $\mathrm{Zn}$ concentration, but the repeated injections did not. Feeding the HP diet increased the response of plasma Zn concentration to the single injection of LPS. Plasma albumin concentration was reduced by LPS injection. Feeding the HP diet resulted in a higher plasma $\alpha$ 1-acid glycoprotein (AGP) concentration than feeding the LP diet, in chicks untreated with LPS. An increase in plasma AGP concentration observed after LPS injection in chicks fed on the LP diet was greater than that seen in chicks fed on the HP diet. No significant changes in plasma AGP concentration in response to repeated injections of LPS were observed in chicks fed on the HP diet. Plasma interleukin-1 (IL-1)-like activity was greater in chicks fed on the LP diet than in those fed on the HP diet, when LPS was injected. The response of plasma IL-1-like activity to the single injection of LPS in chicks fed on the LP diet was the greatest among the treatment groups. These results suggest that acute-phase responses to LPS injection are much greater in chicks fed on a LP diet than in those fed on a HP diet, and multiple injection of LPS weakens the responses.
\end{abstract}

Acute-phase response: Dietary protein: Lipopolysaccharide

Exposure of animals to infectious or inflammatory agents not only induces immune responses in the host, but also causes metabolic changes that lead to decreased rates of gain and feed consumption. Cytokines are involved in communication between immune cells, and between immune cells and other cells of the animal body. Cytokines also act indirectly on the liver by creating a hormonal milieu for enhancing production of acute-phase proteins. Thus, leucocyte products, cytokines, play significant roles in immunity, nutrient metabolism and the endocrine system. It is well known that of all cytokines, interleukin (IL)-1, IL-6 and tumour necrosis factor (TNF) are important regulators of metabolic responses during the early stages of inflammation.

Nutrition can influence the release of IL-1, IL-6 and TNF following an immune response and consequently the outcome of infectious challenges (Klasing, 1988; Klasing \& Barnes, 1988; Grimble, 1990, 1992; Klasing \& Johnstone, 1991). Clinical and experimental animal studies suggest that protein deficiency influences the metabolic responses to endotoxin and modifies the ability of monocytes to produce cytokines (Hoffman-Goetz \& Kluger, 1979; 
Hoffman-Goetz et al. 1981, 1985; Kauffman et al. 1982; Keenan et al. 1982; HoffmanGoetz \& Marcon, 1983; Drabik et al., 1987). There is evidence that both the release rate of IL-1 in stimulated monocytes and the hepatic and hypothalamic responses to the released IL-1 are lowered by protein deficiency, as a decrease in febrile response to endotoxin has been shown in protein-deficient rats (Hoffman-Goetz et al. 1985; Bradley et al. 1987; Bradley \& Kauffman, 1988). However, it is not known how feeding a low-protein (but not protein-free) diet affects IL-1 production or activity and how dietary protein concentration affects acute-phase responses following the repeated stimulation of an immunogen.

Acute-phase proteins are concerned with defence mechanisms against tissue damage and infections (Fleck, 1989; Wan et al. 1989), and may possibly be an indicator of activity or production of IL-6 in chickens (Klasing \& Johnstone, 1991). $\alpha$ 1-Acid glycoprotein (AGP) is an acute-phase protein also present in chicks (Takahashi et al. 1994). Acute-phaseprotein synthesis is probably also influenced by nutritional status, but nutritional modification of the synthesis is not clear as yet even in mammals.

The present study was undertaken to determine the effects of dietary protein concentration, and single or repeated administration of LPS on the acute phase of stress responses in broiler chickens.

\section{MATERIALS AND METHODS}

\section{Animals and diets}

Non-vaccinated male broiler chicks ( $1 \mathrm{~d}$ old) were housed in a battery brooder with electric heating for 1 week. Chicks were selected from a twofold larger population to obtain uniform body weight, and randomly assigned to eight groups of eight chicks, with four replicates of two chicks per cage. The birds were fed ad lib. on a low-protein (LP, $100 \mathrm{~g} / \mathrm{kg}$ ) or a highprotein (HP, $300 \mathrm{~g} / \mathrm{kg}$ ) diet (Table 1) without any antibiotics or anticoccidial drugs for 2 weeks. The protein concentration in the diets was calculated from the nutrient composition of feedstuffs used in poultry diets (National Research Council, 1984). Body weights were determined individually before injection of lipopolysaccharide (LPS) and at the end of the experiment. Feed intake for $14 \mathrm{~d}$ was determined per cage of two chicks and body-weight gain $/ 100 \mathrm{~g}$ feed intake was calculated using the data from two chicks per cage for $14 \mathrm{~d}$.

\section{Preparation and injection of lipopolysaccharide}

Escherichia coli LPS was obtained from Difco Laboratories (Detroit, MI, USA) and dissolved, in sterilized saline $(9 \mathrm{~g} \mathrm{NaCl} / \mathrm{l})$ at a concentration of $900 \mu \mathrm{g} / \mathrm{ml}$. Half of the chicks in each dietary group were injected intraperitoneally once with either $900 \mu \mathrm{g}$ LPS or sterilized saline $16 \mathrm{~h}$ before the end of the experiment. The other half were injected with either the same amount of LPS or the saline every $2 \mathrm{~d}$ during the final $6 \mathrm{~d}$ of the experiment, and the final injection was made at the same time as the groups receiving the single injection.

\section{Preparation of the interleukin-1 fraction from blood}

Blood was taken via a wing vein and plasma was separated by centrifugation ( $500 \mathrm{~g}$, $15 \mathrm{~min}$ ). To prepare the IL-1 fraction, $3 \mathrm{ml}$ plasma, a mixture of equal volumes of plasma obtained from two chicks kept in the same cage, was concentrated by using ultrafiltration (Amicon PM 100; WR Grace \& Co. Conn., Beverly, MA, USA). The resulting solution was passed through membrane filters (Amicon PM 10 and PM 30), yielding filtrates with proteins in the molecular ranges 10000 to 30000 . The filtrates were sterilized by membrane filtration, lyophilized, and stored at $-80^{\circ}$ until analysis. 
Table 1. Compositions $(\mathrm{g} / \mathrm{kg})$ of the low-protein and high-protein chick diets*

\begin{tabular}{|c|c|c|}
\hline Ingredient & $\begin{array}{c}\text { Low } \\
\text { protein }\end{array}$ & $\begin{array}{c}\text { High } \\
\text { protein }\end{array}$ \\
\hline Maize & $890 \cdot 0$ & $369 \cdot 3$ \\
\hline Soyabean meal & $43 \cdot 4$ & $445 \cdot 4$ \\
\hline Soyabean protein & - & $70 \cdot 0$ \\
\hline DL-Methionine & 0.6 & $3 \cdot 9$ \\
\hline L-Lysine & 1.8 & - \\
\hline L-Arginine & $2 \cdot 0$ & - \\
\hline Soyabean oil & $18 \cdot 7$ & $72 \cdot 6$ \\
\hline Calcium carbonate & $13 \cdot 2$ & 11.9 \\
\hline Calcium phosphate & $19 \cdot 4$ & $16 \cdot 1$ \\
\hline Sodium chloride & 2.9 & 2.9 \\
\hline Vitamin mixture $†$ & $4 \cdot 0$ & $4 \cdot 0$ \\
\hline Mineral mixture $\dagger$ & $4 \cdot 0$ & 4.0 \\
\hline Calculated crude protein $(\mathrm{g} / \mathrm{kg}) \ddagger$ & $100 \cdot 0$ & $300 \cdot 0$ \\
\hline
\end{tabular}

* Calculated metabolizable energy was $13.4 \mathrm{MJ} / \mathrm{kg}$ diet for each diet.

† See Akiba \& Matsumoto (1978).

¥ Crude protein content was calculated from feedstuff composition tables (National Research Council, 1984).

\section{Determination of interleukin-1-like activity}

IL-1-like activity was determined by its capacity to augment mitogen-stimulated thymocyte proliferations. Thymuses were obtained from 6-week-old chicks and thymocytes were teased from the thymus through a stainless steel mesh $(<100 \mu \mathrm{m})$. Mononuclear cells of the thymus were isolated by layering the cell sample over 1.077 specific gravity FicollIsopaque and centrifuging $\left(600 \mathrm{~g}\right.$ at $15^{\circ}$ for $\left.50 \mathrm{~min}\right)$. The mononuclear layer was collected and washed three times by centrifuge $\left(650 \mathrm{~g}\right.$ at $15^{\circ}$ for $\left.10 \mathrm{~min}\right)$ in a RPMI-1640 medium. The filtrates containing the IL-1 fraction were dissolved in $300 \mu 1$ RPMI-1640 medium. A $50 \mu \mathrm{l}$ sample of the filtrate was incubated with $2 \times 10^{6}$ thymocytes in ninety-six-well plates and $1 \mu \mathrm{g}$ phytohemagglutinin-P (PHA-P; Difco BRL, New York, USA) per well in the RPMI-1640 medium supplemented with 100 units $/ \mathrm{ml}$ penicillin, $100 \mu \mathrm{g} / \mathrm{ml}$ streptomycin (Difco) and $50 \mathrm{ml} / 1$ autologous serum to give a final volume of $200 \mu \mathrm{l}$. Serum was inactivated at $56^{\circ}$ for $30 \mathrm{~min}$ and sterilized. After incubation in a $50 \mathrm{ml} / 1 \mathrm{CO}_{2}$, humidified atmosphere at $42^{\circ}$ for $54 \mathrm{~h}$, each well was pulsed with $37 \mathrm{~Bq}\left[{ }^{3} \mathrm{H}\right]$ thymidine and incubated for an additional $16 \mathrm{~h}$. Cells were harvested onto glass-fibre filters with a cell harvester and isotope incorporation into DNA was determined by scintillation counting. The results were expressed as disintegrations/min (dpm).

\section{Determination of a 1-acid glycoprotein, albumin, iron and zinc concentrations}

Plasma AGP concentration was determined using chicken AGP plate (single immunodiffusion; Saikin Kagaku Institute, Sendai, Japan), incorporating specific anti-chicken AGP serum of rabbit origin in agarose gel as described previously (Takahashi et al. 1994). Plasma albumin concentration was determined by an assay kit obtained from Wako Pure Chemicals Ltd (Osaka, Japan). Plasma Zn and Fe concentrations were determined by assay kits (Wako Pure Chemicals) based on colourimetric determinations using 2-(5-bromo-2pyridylazo)-5-(N-n-propyl-N-3-sulfopropylamino)-phenol (Makino et al. 1982) and 2-nitroso-5-(N-propyl-N-sulfopropylamino)-phenol (Saito et al. 1981) respectively. Measurements of these variables were carried out in the plasma of individual chicks. 
Table 2. Effects of a single injection of Escherichia coli lipopolysaccharide (LPS; $900 \mu \mathrm{g} /$ chick) and dietary protein concentration on body-weight gain, feed intake and gain:intake ratio in broiler chickenst

(Mean values with their standard errors)

\begin{tabular}{|c|c|c|c|c|c|c|c|c|c|c|c|}
\hline \multirow{3}{*}{\multicolumn{2}{|c|}{$\begin{array}{l}\text { Protein concentration } \\
(\mathrm{g} / \mathrm{kg})\end{array}$}} & \multicolumn{6}{|c|}{ Body-wt gain $\ddagger$} & \multirow{2}{*}{\multicolumn{2}{|c|}{$\begin{array}{c}\text { Feed } \\
\text { intake\$ } \\
\text { (g/14 d) }\end{array}$}} & \multirow{2}{*}{\multicolumn{2}{|c|}{$\begin{array}{l}\text { Weight } \\
\text { gain:feed } \\
\text { intake for } \\
14 \mathrm{~d} \S \\
(\mathrm{g} / 100 \mathrm{~g})\end{array}$}} \\
\hline & & \multicolumn{2}{|c|}{$\begin{array}{l}\text { Before LPS } \\
\text { injection } \\
(\mathrm{g})\end{array}$} & \multicolumn{2}{|c|}{$\begin{array}{l}\text { After LPS } \\
\text { injection } \\
(\mathrm{g})\end{array}$} & \multicolumn{2}{|c|}{$\begin{array}{l}\text { Overall } \\
(\mathrm{g} / 14 \mathrm{~d})\end{array}$} & & & & \\
\hline & & Mean & $\mathrm{SE}$ & Mean & $\mathrm{SE}$ & Mean & $\mathrm{SE}$ & Mean & $\mathrm{SE}$ & Mean & SE \\
\hline & Saline & 208 & 10 & 15 & 6 & 225 & 12 & 687 & 11 & $33 \cdot 1$ & 1.6 \\
\hline & LPS & 190 & 11 & 5 & 3 & 194 & 11 & 630 & 21 & $30 \cdot 8$ & $1 \cdot 3$ \\
\hline \multirow[t]{2}{*}{300} & Saline & 495 & 17 & 35 & 7 & 530 & 19 & 801 & 11 & $66 \cdot 1$ & $2 \cdot 0$ \\
\hline & LPS & 490 & 15 & 25 & 5 & 515 & 16 & 830 & 15 & $62 \cdot 2$ & $2 \cdot 2$ \\
\hline \multicolumn{12}{|c|}{ Analysis of variance, $P$} \\
\hline \multicolumn{2}{|c|}{ Protein concentration } & \multicolumn{2}{|c|}{ ** } & \multicolumn{2}{|c|}{ ** } & \multicolumn{2}{|c|}{$* *$} & \multicolumn{2}{|c|}{ ** } & \multicolumn{2}{|c|}{$* *$} \\
\hline \multirow{2}{*}{\multicolumn{2}{|c|}{ LPS injection }} & \multicolumn{2}{|c|}{ - } & \multirow{2}{*}{\multicolumn{2}{|c|}{$\begin{array}{l}\text { NS } \\
\text { NS }\end{array}$}} & \multirow{2}{*}{\multicolumn{2}{|c|}{$\begin{array}{l}\text { NS } \\
\text { NS }\end{array}$}} & \multirow{2}{*}{\multicolumn{2}{|c|}{$\begin{array}{l}\text { NS } \\
\text { NS }\end{array}$}} & \multirow{2}{*}{\multicolumn{2}{|c|}{ NS }} \\
\hline Interactions & & \multicolumn{2}{|c|}{ - } & & & & & & & & \\
\hline
\end{tabular}

NS, not significant.

** $P<0.01$.

$\uparrow$ For details of diets and procedures, see Table 1 and p. 174.

$+n 8$.

$\S$ Calculated on the basis of two chicks/cage $(n 4)$.

\section{Statistical analysis}

A 2 (dietary protein concentration) $\times 2$ (the injection procedure, the LPS and saline injections) factorial experimental test was applied to analyse the data in each of the experiments (single and repeated injections) and the calculation was carried out using the General Linear Model of SAS (SAS Institute, Cary NC, USA).

\section{RESULTS}

Table 2 shows the effect of a single injection of LPS on body-weight gain, feed intake and gain : intake ratio in chicks fed on the LP or HP diets. The LPS injection did not affect bodyweight gain, feed intake or body-weight gain:feed intake ratio over $14 \mathrm{~d}$.

Table 3 shows the effect of a single injection of LPS on plasma concentrations of $\mathrm{Fe}, \mathrm{Zn}$, albumin and AGP, and plasma IL-1-like activity in chicks fed on the LP or HP diets. Plasma Zn concentration was decreased by LPS injection and the decrease in chicks fed on the HP diet was substantial compared with that of chicks fed on the LP diet. Neither LPS injection nor dietary protein concentration affected plama Fe concentration. In chicks fed on the HP diet plasma albumin concentration was higher than that of chicks fed on the LP diet, and was reduced by LPS injection. Plasma AGP concentration was higher in chicks fed on the HP diet than those fed on the LP diet. The single injection of LPS resulted in a fivefold increase in plasma AGP concentration in chicks fed on the LP diet compared with their saline-control counterparts, whereas those given the HP diet showed about a threefold increase. Plasma IL-1-like activity after LPS injection in chicks fed on the LP diet was five times greater than that in the saline-injected control, whereas LPS injection in chicks fed on the HP diet resulted in approximately the same activity as in the control birds.

Table 4 shows the effect of repeated injections of LPS on body-weight gain, feed intake 
Table 3. Effects of a single injection of Escherichia coli lipopolysaccharide (LPS; $900 \mu \mathrm{g} /$ chick) and dietary protein concentration on plasma concentrations of iron, zinc, albumin and $\alpha$ l-acid glycoprotein $(A G P)$, and plasma interleukin-l $(I L-1)$ activity in broiler chickens $\dagger$

(Mean values with their standard errors)

\begin{tabular}{|c|c|c|c|c|c|c|c|c|c|c|c|}
\hline \multirow{2}{*}{\multicolumn{2}{|c|}{$\begin{array}{l}\text { Protein concentration } \\
(\mathrm{g} / \mathrm{kg})\end{array}$}} & \multicolumn{2}{|c|}{$\begin{array}{l}\text { Iron } \ddagger \\
(\mu \mathrm{g} / 1)\end{array}$} & \multicolumn{2}{|c|}{$\begin{array}{l}\text { Zincł } \\
(\mu \mathrm{g} / 1)\end{array}$} & \multicolumn{2}{|c|}{$\underset{(\mathrm{mg} / \mathrm{ml})}{\text { Albumin }}$} & \multicolumn{2}{|c|}{$\begin{array}{c}\text { AGP } \ddagger \\
(\mu \mathrm{g} / \mathrm{ml})\end{array}$} & \multicolumn{2}{|c|}{$\begin{array}{c}\text { IL-1-like } \\
\text { activity\$\| } \\
\left(\mathrm{dpm} \times 10^{3}\right)\end{array}$} \\
\hline & & Mean & $\mathrm{SE}$ & Mean & $\mathrm{SE}$ & Mean & $\mathrm{SE}$ & Mean & SE & Mean & SE \\
\hline \multirow[t]{2}{*}{100} & Saline & 910 & 70 & 1730 & 80 & $8 \cdot 8$ & 0.5 & 179 & 23 & 1.09 & $0 \cdot 27$ \\
\hline & LPS & 650 & 80 & 1520 & 60 & $7 \cdot 5$ & 0.3 & 832 & 65 & $5 \cdot 61$ & 0.59 \\
\hline \multirow[t]{2}{*}{300} & Saline & 690 & 80 & 1620 & 120 & $11 \cdot 5$ & 0.4 & 323 & 30 & $1 \cdot 10$ & $0 \cdot 18$ \\
\hline & LPS & 640 & 80 & 980 & 80 & $10 \cdot 2$ & 0.5 & 983 & 73 & $1 \cdot 14$ & 0.34 \\
\hline \multicolumn{12}{|c|}{ Analysis of variance, $P$} \\
\hline \multicolumn{2}{|c|}{ Protein concentration } & \multicolumn{2}{|c|}{ NS } & \multicolumn{2}{|c|}{ * } & \multicolumn{2}{|c|}{ ** } & \multicolumn{2}{|c|}{ * } & \multicolumn{2}{|c|}{ ** } \\
\hline \multicolumn{2}{|c|}{ LPS injection } & \multicolumn{2}{|c|}{ NS } & \multicolumn{2}{|c|}{ ** } & \multicolumn{2}{|c|}{ ** } & \multicolumn{2}{|c|}{ ** } & \multicolumn{2}{|c|}{ ** } \\
\hline \multicolumn{2}{|c|}{ Interactions } & \multicolumn{2}{|c|}{ NS } & \multicolumn{2}{|c|}{ * } & \multicolumn{2}{|c|}{ NS } & \multicolumn{2}{|c|}{ NS } & \multicolumn{2}{|c|}{$* *$} \\
\hline
\end{tabular}

NS, not significant.

$* P<0.05, \quad * * P<0.01$.

$\dagger$ For details of diets and procedures, see Table 1 and pp. 174-176.

$\ddagger n 8$.

$\S n 4$.

II The value for $\left[{ }^{3} \mathrm{H}\right]$ thymidine in thymocytes incubated with the medium plus phytohaemagglutinin- $\mathrm{P}$ was 960 (SE 54) dpm ( $n$ 4).

Table 4. Effects of repeated (three times) injections of Escherichia coli lipopolysaccharide (LPS; $900 \mu \mathrm{g} / \mathrm{chick}$ ) and dietary protein concentration on body-weight gain, feed intake and gain: intake ratio in broiler chickenst

(Mean values with their standard errors)

\begin{tabular}{|c|c|c|c|c|c|c|c|c|c|c|c|}
\hline \multirow{3}{*}{\multicolumn{2}{|c|}{$\begin{array}{l}\text { Protein concentration } \\
(\mathrm{g} / \mathrm{kg})\end{array}$}} & \multicolumn{6}{|c|}{ Body-wt gain } & \multirow{2}{*}{\multicolumn{2}{|c|}{$\begin{array}{l}\text { Feed intake } \delta \\
(g / 14 d)\end{array}$}} & \multirow{2}{*}{\multicolumn{2}{|c|}{$\begin{array}{c}\text { Weight } \\
\text { gain: feed } \\
\text { intake for } \\
14 \mathrm{~d} \S \\
(\mathrm{g} / 100 \mathrm{~g})\end{array}$}} \\
\hline & & \multicolumn{2}{|c|}{$\begin{array}{c}\text { Before LPS } \\
\text { injection } \\
(\mathrm{g} / 8 \mathrm{~d})\end{array}$} & \multicolumn{2}{|c|}{$\begin{array}{c}\text { After LPS } \\
\text { injection } \\
(\mathrm{g} / 6 \mathrm{~d})\end{array}$} & \multicolumn{2}{|c|}{$\begin{array}{l}\text { Overall } \\
(\mathrm{g} / 14 \mathrm{~d})\end{array}$} & & & & \\
\hline & & Mean & SE & Mean & $\mathbf{S E}$ & Mean & SE & Mean & $\mathrm{SE}$ & Mean & $\mathrm{SE}$ \\
\hline \multirow[t]{2}{*}{100} & Saline & 104 & 8 & 90 & 5 & 193 & 11 & 656 & 8 & $29 \cdot 5$ & 1.4 \\
\hline & LPS & 110 & 12 & 78 & 10 & 188 & 18 & 632 & 12 & $29 \cdot 7$ & $2 \cdot 8$ \\
\hline \multirow[t]{2}{*}{300} & Saline & 238 & 16 & 264 & 14 & 500 & 25 & 822 & 15 & $61 \cdot 3$ & $3 \cdot 6$ \\
\hline & LPS & 258 & 14 & 265 & 9 & 523 & 19 & 828 & 16 & $63 \cdot 3$ & $2 \cdot 4$ \\
\hline \multicolumn{12}{|c|}{ Analysis of variance, $P$} \\
\hline \multicolumn{2}{|c|}{ Protein concentration } & \multicolumn{2}{|c|}{ ** } & \multicolumn{2}{|c|}{$* *$} & \multicolumn{2}{|c|}{$* *$} & \multicolumn{2}{|c|}{ ** } & \multicolumn{2}{|c|}{$* *$} \\
\hline \multicolumn{2}{|c|}{ LPS injection } & \multicolumn{2}{|c|}{ - } & \multicolumn{2}{|c|}{ NS } & \multicolumn{2}{|c|}{ NS } & \multicolumn{2}{|c|}{ NS } & \multicolumn{2}{|c|}{ NS } \\
\hline \multicolumn{2}{|c|}{ Interactions } & \multicolumn{2}{|c|}{ - } & \multicolumn{2}{|c|}{ NS } & \multicolumn{2}{|c|}{ NS } & \multicolumn{2}{|c|}{ NS } & \multicolumn{2}{|c|}{ NS } \\
\hline
\end{tabular}

NS, not significant.

** $P<0.01$.

$\uparrow$ For details of diets and procedures, see Table 1 and p. 174.

$\ddagger n 8$.

$\S$ Calculated on the basis of two chicks/cage $(n 4)$. 
Table 5. Effects of repeated injections (three times) of Escherichia coli lipopolysaccharide (LPS; $900 \mu \mathrm{g} /$ chick) and dietary protein concentration on plasma concentrations of iron, zinc, albumin and a 1 -acid glycoprotein (AGP), and plasma interleukin-1 (IL-1) activity in broiler chickens $\dagger$

(Mean values with their standard errors)

\begin{tabular}{|c|c|c|c|c|c|c|c|c|c|c|c|}
\hline \multirow{2}{*}{\multicolumn{2}{|c|}{$\begin{array}{l}\text { Protein concentration } \\
(\mathrm{g} / \mathrm{kg})\end{array}$}} & \multicolumn{2}{|c|}{$\begin{array}{l}\text { Iron } \ddagger \\
(\mu \mathrm{g} / 1)\end{array}$} & \multicolumn{2}{|c|}{$\begin{array}{l}\text { Zincf } \\
(\mu \mathrm{g} / \mathrm{l})\end{array}$} & \multicolumn{2}{|c|}{$\underset{(\mathrm{mg} / \mathrm{ml})}{\text { Albumin }}$} & \multicolumn{2}{|c|}{$\begin{array}{c}\mathrm{AGP} \ddagger \\
(\mu \mathrm{g} / \mathrm{ml})\end{array}$} & \multicolumn{2}{|c|}{$\begin{array}{c}\text { IL-1-like } \\
\text { activity§\| } \\
\left(\mathrm{dpm} \times 10^{3}\right)\end{array}$} \\
\hline & & Mean & $\mathrm{SE}$ & Mean & $\mathrm{SE}$ & Mean & $\mathrm{SE}$ & Mean & $\mathrm{SE}$ & Mean & $\mathrm{SE}$ \\
\hline \multirow[t]{2}{*}{100} & Saline & 1020 & 80 & 1790 & 60 & 8.8 & $0 \cdot 6$ & 179 & 6 & $1 \cdot 21$ & 0.24 \\
\hline & LPS & 990 & 70 & 1620 & 80 & 7.5 & $0 \cdot 3$ & 522 & 64 & $2 \cdot 01$ & 0.65 \\
\hline \multirow[t]{2}{*}{300} & Saline & 920 & 40 & 1750 & 140 & $12 \cdot 4$ & 0.5 & 338 & 14 & $1 \cdot 10$ & $0 \cdot 13$ \\
\hline & LPS & 800 & 60 & 1840 & 100 & $11 \cdot 2$ & $0-3$ & 364 & 32 & $1 \cdot 71$ & 0.68 \\
\hline \multicolumn{12}{|c|}{ Analysis of variance, $P$} \\
\hline \multirow{2}{*}{\multicolumn{2}{|c|}{ Protein concentration }} & \multicolumn{2}{|c|}{ NS } & \multicolumn{2}{|c|}{ NS } & \multicolumn{2}{|c|}{ ** } & \multicolumn{2}{|c|}{$*$} & \multicolumn{2}{|c|}{ NS } \\
\hline & & \multirow{2}{*}{\multicolumn{2}{|c|}{ NS }} & \multirow{2}{*}{\multicolumn{2}{|c|}{$\begin{array}{l}\text { NS } \\
\text { NS }\end{array}$}} & \multirow{2}{*}{\multicolumn{2}{|c|}{$\begin{array}{l}* * \\
\text { NS }\end{array}$}} & & & & \\
\hline \multicolumn{2}{|c|}{$\begin{array}{l}\text { LPS injection } \\
\text { Interactions }\end{array}$} & & & & & & & \multicolumn{2}{|c|}{ * } & \multicolumn{2}{|c|}{ NS } \\
\hline
\end{tabular}

NS, not significant.

$* P<0.05, \quad * * P<0.01$.

$\dagger$ For details of diets and procedures, see Table 1 and pp. 174-176.

$+n 8$.

$\S n 4$.

\| The value for $\left[{ }^{3} \mathrm{H}\right]$ thymidine in thymocytes incubated with the medium plus phytohaemagglutinin-P was 960 (SE 54) dpm ( $n$ 4).

and gain: intake ratio in chicks fed on the LP or HP diets. LPS injection did not affect bodyweight gain for $6 \mathrm{~d}$ after starting the injections, and did not affect feed intake, or bodyweight gain: feed intake ratio for $14 \mathrm{~d}$.

Table 5 shows the effect of repeated injections of LPS on plasma concentrations of $\mathrm{Fe}$, $\mathrm{Zn}$, albumin and AGP, and plasma IL-1-like activity in chicks fed on the LP or HP diets. Neither plasma Fe nor Zn concentration was influenced by LPS injection or dietary protein concentration. Plasma albumin concentration was higher in chicks fed on the HP diet than in chicks fed on the LP diet, and was reduced by LPS injection. Plasma AGP concentration was increased by repeated LPS injections in chicks fed on the LP diet, but not in chicks fed on the HP diet. Plasma IL-1-like activity was increased by 1.5 to 2 times the control after repeated LPS injections, whereas no significant effect of dietary protein level on the IL-1like activity was observed.

\section{DISCUSSION}

Klasing et al. (1987) reported reduction of growth and feed utilization in a model system for studying immunologic stress by frequent injections of immunogens such as LPS, sheep erythrocytes and Sephadex in chicks under controlled laboratory conditions. In the present experiment we were not able to induce any changes in growth and feed utilization by repeated injections of LPS even using a similar model to that of Klasing et al. (1987). Changes in growth following immunogen injections appeared to be modified by the diet composition: feeding a soyabean-maize-based diet caused a greater response to immunogen than when maize-maize-gluten-based and carbohydrate-rich diets were fed (Klasing $e t$ al. 1987; Benson et al. 1993). The diets used in the present experiment were similar in composition and ingredients to those of Klasing et al. (1987), in which significant 
immunogen-related reductions in body weight and feed intake were found after repeated injections of immunogen. A possible explanation of the conflict in results may be the differences in serotype of LPS used (Curtis \& Flack, 1980) and/or dosage of LPS (Johnson et al. 1993).

Repeated injections of LPS reduced the response of plasma IL-1-like activity compared with the single LPS injection in the present experiment. Friedman et al. (1992) showed that continuous endotoxin infusion suppressed rat spleen cell production of cytokines including IL-1. It is, therefore, concluded that repeated or continuous LPS administration weakens the response of IL-1 production in chicks as well. It is known that immunogen increases the production or release of IL-1 from monocytes and/or macrophages and glucocorticoid hormones through stimulation of the pituitary-adrenal axis (Klasing, 1988; Grimble, 1990, 1992; Klasing \& Johnstone, 1991). The enhanced IL-1 activity also stimulates hepatocytes to elaborate acute-phase protein (Grimble, 1990, 1992). Glucocorticoids (Besedovsky et al. 1986; Guyre et al. 1988) and some of the acute-phase proteins, including AGP (Bories et al. 1990), inhibit IL-1 production. Thus, immunoregulatory feedback systems exist between IL-1 and glucocorticoids and/or some acute-phase proteins. Therefore, the reduced responsiveness to multiple injections of LPS in the present study with chickens may have been elucidated by the mechanisms considered in mammals.

A protein-deficient diet is known to reduce the metabolic responses to endotoxin and the ability of monocytes to produce cytokines (Hoffman-Goetz \& Kluger, 1979; HoffmanGoetz et al. 1981, 1985; Kauffman et al. 1982; Keenan et al. 1982; Hoffman-Goetz \& Marcon, 1983; Drabik et al. 1987). In most of the studies with mammals the effects of IL-1 on animals fed on a low-protein or protein-free diet were estimated by thermoeffector responses to IL-1 from macrophage culture or endotoxin. The present study showed that the production of IL-1-like substances following the single injection of LPS was enhanced to a greater extent in chicks fed on the LP diet than in chicks fed on the HP diet, regardless of the LPS injection programme. These results indicate that a moderately low protein concentration in the diet increases the response of IL-1 production compared with a high dietary protein concentration. However, Hannum et al. (1990) and Eisenberg et al. (1990) showed that human monocytes induce the IL-1-receptor antagonist (18-22 kDa) which could be important for in vivo regulation of IL-1 activity, and that expression of the cDNA in $E$. coli yields IL-1-receptor-antagonist activity. The findings suggest that the enhanced IL-1 activity in chicks fed on the LP diet may be due to the lower production of the IL-1 antagonist rather than higher synthesis of IL-1, or that feeding the HP diet may induce the antagonist to a greater extent than the LP diet in the procedure for determination of the IL-1 activity. However, Bradley \& Kauffman (1988) observed that, in rats fed on a normalprotein diet, there was a reduction in febrile response to IL-1-containing supernatant fractions from macrophage cultures prepared from rats fed on a low-protein diet, and suggested that IL-1 production estimated by macrophage yield in rats fed on a low-protein diet was lower than that in rats fed on the control diet. The observations of Bradley \& Kauffman (1988) and those from the present study suggest that changes in the IL-1 activity in animals fed on a low-protein diet cannot be explained by changes in the production of IL-1 receptor antagonist alone. Moreover, there is no direct evidence that dietary protein concentration affects the production of the antagonist. Further studies are needed to account for the different responses of IL-1 to dietary protein concentration between the present experiment and the previous studies with mammals.

Although dietary protein deprivation has a greater effect on IL-1 production than energy restriction (Hoffman-Goetz et al. 1985), energy restriction also affects production of IL-1 in monocytes (Hoffman-Goetz \& Marcon, 1983). Moreover, a low-energy diet and/or fasting enhance various immune effector mechanisms, possibly as a consequence of 
increasing macrophage activity (Wing et al. 1983). It is likely that the enhanced response of IL-1 activity to the LP diet might be caused not only by dietary protein concentration, but also by energy intake, since feed intake was lower in chicks fed on the LP diet than the HP diet. Generally, nutrient deficiencies reduce IL-1 production or activity; e.g. deficiencies of dietary sulphur amino acids (Klasing \& Barnes, 1988) in chicks, Zn (Flynn et al. 1984; Winchurch, 1988), Fe (Helyar \& Sherman, 1987) in rats, or certain vitamins (Trechsel et al. 1985). However, the present study showed that chicks fed on the LP diet responded well to the LPS injection in terms of plasma IL-1 activity, although the LP diet did not contain enough protein to achieve optimal growth and feed utilization. In addition, combined with the responses of the other indicators of the acute-phase responses in this experiment, feeding a low protein (but not protein-free) diet might be enough to maintain or develop the ability for stress responses to LPS in chicks.

Amrani et al. (1986) showed that an IL-6-like factor appears to be an active monokine which augments the synthesis of acute-phase proteins. Thus, IL-6 activity can possibly be estimated from acute-phase-protein production in chicks (Klasing \& Johnstone, 1991). AGP is an acute-phase protein produced following inflammation in chicks (Takahashi et al. 1994). The changes in plasma AGP concentration in the present study suggested that IL- 6 production was not regulated completely in the same manner as IL-1 production.

We have already shown that multiple injection of LPS reduces the response of plasma AGP concentration (Takahashi et al. 1994). This is in good agreement with the present result. Acute-phase proteins are involved in defence mechanisms against tissue damage and infections (Fleck, 1989; Wan et al. 1989). Plasma AGP has been reported to inhibit blastogenesis in man (Bennett \& Schmid, 1980) and secretion of antibodies (Chiu et al. 1977). Suppression of lymphocyte blastogenesis in cattle with experimentally induced hepatic abscesses was highly correlated to serum AGP concentration (Motoi et al. 1992). AGP appears to be an important binding protein for catecholamines (Sager et al. 1987) which are secreted during the acute-phase response to stress. Protein-binding has been shown to diminish the biological effects of catecholamines although the physiological significance of catecholamine-binding in serum is obscure (Powis, 1975). In addition, murine peritoneal macrophages released a factor with inhibitory activity towards the proliferative effect of IL-1 on thymocytes when thymocytes were exposed to AGP (Bories et al. 1990). Thus, AGP has a suppressive effect on IL-1 production in mammals. In the present study, plasma AGP concentration in chicks fed on the HP diet was higher than that of chicks fed on the LP diet, indicating that a HP diet has the potential to suppress the response to LPS compared with a LP diet. This would possibly be a reason for the relatively low acute-phase responses following LPS injections in chicks fed on the HP diet in this study, although the role of AGP in stress and immune response in chicks has not been well elucidated.

A recent study in cultured rat hepatocytes showed that production of acute-phase protein was directly associated with IL-6, corticosterone and Zn status, but not with IL-1 alone (Coyle et al. 1993). It also showed that incubation of IL-1 with corticosterone and $\mathrm{Zn}$ in rat hepatocytes enhanced production of acute-phase protein. Thus $\mathrm{Zn}$ status may be important in producing acute-phase protein in the liver. Generally, an immunogen injection reduces plasma $\mathrm{Zn}$ and $\mathrm{Fe}$ concentrations and then increases the mineral concentrations in the liver (Beisel, 1977). When animals cope with the stress, the concentrations recover before the injection (Beisel, 1977). Furthermore, Laurin \& Klasing (1987) indicated with chicks that the changes in the status of trace minerals such as $\mathrm{Fe}, \mathrm{Zn}$ and $\mathrm{Cu}$, to immunogenic challenges were dependent on the number of immunogen injections and the nutritional state of the animals; the changes in the mineral concentration in the liver following repeated injection were greater than those due to the single injection. The present 
study showed that multiple injections of LPS reduced or diminished the responses of $\mathrm{Zn}$ and IL-1. These observations suggest that lack of AGP response after multiple injections of LPS may be related, in part, to a reduced response of IL-1 and $\mathrm{Zn}$.

\section{REFERENCES}

Akiba, Y. \& Matsumoto, T. (1978). Effect of force-feeding and dietary cellulose on liver lipid accumulation and lipid composition of liver and plasma in growing chicks. Journal of Nutrition 108, 739-748.

Amrani, D. L., Mauzy-Melity, D. \& Mossessen, M. W. (1986). Effect of hepatic-stimulating factor and glucocorticoids on plasma fibronectin level. Biochemical Journal 238, 365-371.

Beisel, W. R. (1977). Magnitude of the host nutritional responses to infection. American Journal of Clinical Nutrition 30, 1239-1247.

Bennett, M. \& Schmid, K. (1980). Immunosuppression by human plasma $\alpha 1$ acid glycoprotein: importance of the carbohydrate moiety. Proceedings of the National Academy of Sciences USA 77, 6109-6113.

Benson, B. N., Calvert, C. C., Roura, E. \& Klasing, K. C. (1993). Dietary energy source and density modulate the expression of immunologic stress in chicks. Journal of Nutrition 123, 1714-1723.

Besedovsky, H., Rey, A. D., Sorkin, E. \& Dinarello, C. A. (1986). Immunoregulatory feedback between interleukin-1 and glucocorticoid hormones. Science 233, 652-654.

Bories, P. N., Feger, J., Benbernou, N., Rouzeau, J.-D., Agneray, J. \& Durand, G. (1990). Prevalence of tri- and tetraantennary glycans of human alpha 1-acid glycoprotein in release of macrophage inhibitor of interleukin1 activity. Inflammation 14, 315-323.

Bradley, S. F. \& Kauffman, C. A. (1988). Protein malnutrition and the febrile response in the Fisher rat. Journal of Leukocyte Biology 43, 36-40.

Bradley, S. F., Kuluger, M. J. \& Kauffman, C. A. (1987). Age and protein malnutrition effects on the febrile response. Gerontology 33, 99-108.

Chiu, K. M., Mortensen, R. F., Osmond, A. P. \& Gewurz, H. (1977). Interactions of alpha 1-acid glycoprotein with the immune system. Immunology 32, 997-1005.

Coyle, P., Philcox, J. C. \& Rofe, A. M. (1993). Corticosterone enhances the zinc and interleukin-6-mediated induction of metallothionein in cultured rat hepatocytes. Journal of Nutrition 123, 1464-1470.

Curtis, M. J. \& Flack, I. H. (1980). The effect of Escherichia coli endotoxins on the concentration of corticosterone and growth hormone in the plasma of the domestic fowl. Research of Veterinary Science 28, 123-127.

Drabik, M. D., Schnure, F. C., Mok, K. T., Moldawer, L. L., Dinarello, C. A., Blackburn, G. L. \& Bistrian, B. R. (1987). Effect of protein depletion and short-term parenteral refeeding on the host response to interleukin1 administration. Journal of Laboratory and Clinical Medicine 109, 509-516.

Eisenberg, S. P., Evans, R. J., Arend, W. P., Verderber, E., Brewer, M. T., Hannum, C. H. \& Thompson, R. C. (1990). Primary structure and functional expression from complementary DNA of a human interleukin-1 receptor antagonist. Nature 343, 341-346.

Fleck, A. (1989). Clinical and nutritional aspects of changes in acute-phase proteins during inflammation. Proceedings of the Nutrition Society 48, 347-354.

Flynn, A., Loftus, M. A. \& Finke, J. H. (1984). Production of interleukin-1 and interleukin-2 in allogeneic mixed lymphocyte cultures under copper, magnesium and zinc deficient conditions. Nutrition Research 4 , 673-679.

Friedman, H., Newton, C., Widen, R., Klein, T. \& Spitzer, J. D. (1992). Continuous endotoxin infusion suppresses rat spleen cell production of cytokines. Proceedings of the Society for Experimental Biology and Medicine 199, 360-364.

Grimble, R. F. (1990). Nutrition and cytokine action. Nutrition Research Reviews 3, 193-210.

Grimble, R. F. (1992). Dietary manipulation of the inflammatory response. Proceedings of the Nutrition Society 51, $285-294$.

Guyre, P. M., Girard, M. T., Morganelli, P. M. \& Manganiello, P. D. (1988). Glucocorticoid effects on the production and actions of immune cytokines. Journal of Steroid Biochemistry 30, 89-93.

Hannum, C. H., Wilcox, C. J., Arend, P. A., Joslin, G., Dripps, D. J., Heimdal, P. L., Armes, L. G., Sommer, A., Eisenberg, S. P. \& Thompson, R. C. (1990). Interleukin-1 receptor antagonist activity of a human interleukin1 inhibitor. Nature $343,336-340$.

Helyar, L. \& Sherman, A. R. (1987). Iron deficiency and interleukin-1 production by rat leukocytes. American Journal of Clinical Nutrition 46, 346-352.

Hoffman-Goetz, L., Bell, R. C. \& Keir, R. (1985). Effect of protein malnutrition and interleukin-1 on in vivo rabbit lymphocyte mitogenesis. Nutrition Research 5, 769-780.

Hoffman-Goetz, L. \& Kluger, M. J. (1979). Protein deprivation: its effects on fever and plasma iron during bacterial infection in rabbits. Journal of Physiology 295, 419-430.

Hoffman-Goetz, L., McFarlane, D., Bistrian, B. R. \& Blackburn, G. L. (1981). Febrile and plasma iron responses of rabbits injected with endogenous pyrogen from malnourished patients. American Journal of Clinical Nutrition 34, 1109-1116. 
Hoffman-Goetz, L. \& Marcon, T. (1983). Effect of in vitro amino acid supplementation on endogenous pyrogen fever. Nutrition Research 3, 237-241.

Johnson, R. W., Curtis, S. E., Dantzer, R., Bahr, J. M. \& Kelley, K. W. (1993). Sickness behavior in birds caused by peripheral or central injection of endotoxin. Physiology and Behavior 53, 343-348.

Kauffman, R. A., Jones, P. G. \& Kluger, M. J. (1982). Fever and malnutrition: endogenous pyrogen/interleukin1 in malnourished patients. American Journal of Clinical Nutrition 44, 449-452.

Keenan, R. A., Modawer, L. L., Yang, R. D., Kawamura, I., Blackburn, G. L. \& Bistrian, R. R. (1982). An altered response by peripheral leukocytes to synthesize or release leukocyte endogenous mediator in critically ill protein-malnourished patients. Journal of Laboratory and Clinical Medicine 100, 844-857.

Klasing, K. C. (1988). Nutritional aspects of leukocytic cytokines. Journal of Nutrition 118, 1436-1446.

Klasing, K. C. \& Barnes, D. M. (1988). Decreased amino acid requirements of growing chicks due to immunologic stress. Journal of Nutrition 118, 1158-1164.

Klasing, K. C. \& Johnstone, B. J. (1991). Monokines in growth and development. Poultry Science 70, 1781-1789.

Klasing, K. C., Laurin, D. E., Peng, R. K. \& Fry, D. M. (1987). Immunologically mediated growth depression in chicks: influence of feed intake, corticosterone and interleukin-1. Journal of Nutrition 117, 1629-1637.

Laurin, D. E. \& Klasing, K. C. (1987). Effects of repetitive immunogen injections and fasting versus feeding on iron, zinc and copper metabolism in chicks. Biological Trace Element Research 14, 153-165.

Makino, T., Saito, M., Horiguchi, S. \& Kina, K. (1982). A highly sensitive colorimetric determination of serum zinc using water-soluble pyridylazo dye. Clinica Chimica Acta 120, 127-135.

Motoi, Y., Itoh, H., Tamura, K., Miyamoto, T., Ohashi, T. \& Nagasawa, S. (1992). Correlation of serum concentration of alpha 1-acid glycoprotein with lymphocyte blastogenesis and development of experimentally induced or naturally acquired hepatic abscesses in cattle. American Journal of Veterinary Research 53, 574-579.

National Research Council (1984). Nutrient Requirements of Poultry, 8th revised ed., pp. 35-47. Washington, DC: National Academic Press.

Powis, G. (1975). Binding of catecholamines to human serum. Biochemical Pharmacology 24, 707-712.

Sager, G., Bratlid, H. \& Lettle, C. (1987). Binding of catecholamines to alpha-1 acid glycoprotein, albumin and lipoproteins in human serum. Biochemical Pharmacology 36, 3607-3612.

Saito, M., Horiguchi, D. \& Kina, K. (1981). Spectrophotometric determination of tracers of iron(II) with novel water-soluble nitrosophenol derivatives (in Japanese). Bunseki Kagaku 30, 635-639.

Takahashi, K., Kaji, N., Akiba, Y. \& Tamura, K. (1994). Plasma alpha-1 acid glycoprotein concentration in broilers: influence of age, sex and injection of Escherichia coli lipopolysaccharide. British Poultry Science 35, 507-511.

Trechsel, U., Wener, L. \& Watson, R. R. (1985). Stimulation of interleukin 1 and 3 production by retinoic acid in vitro. Biochemical Journal 230, 339-344.

Wan, J. M. F., Haw, M. P. \& Blackburn, G. L. (1989). Nutrition, immune function, and inflammation: an overview. Proceedings of the Nutrition Society 48, 315-335.

Winchurch, R. A. (1988). Activation of thymocyte response to Interleukin-1 by zinc. Clinical Immunology and Immunopathology 47, 174-180.

Wing, E. J., Stanko, R. T., Winkelstein, A. \& Adibi, S. A. (1983). Fasting-enhanced immune effector mechanisms in obese subjects. American Journal of Medicine 75, $91-96$. 